\title{
EFFECT OF DIFFERENT TYPES AND LEVELS OF ENZYMATIC ANTIOXIDANTS ON SOME CHARACTERISTICS AND FERTILITY OF BUFFALO SPERMATOZOA OF FROZEN SEMEN
}

\author{
Sh. A. Gabr \\ Department of Animal Production, Faculty of Agriculture, University of Tanta
}

\section{SUMMARY}

The effects of different types and levels of enzymatic antioxidants including catalase (CAT), reduced glutathione (GSH) and superoxide dismutase (SOD) added to Tris-egg yolk extender (TEYE) on some characteristics and fertility of buffalo spermatozoa in frozen semen. Semen was collected twice weekly by artificial vagina from five sexually mature Egyptian buffalo bulls and held in a water bath at $35-37^{\circ} \mathrm{C}$. Ejaculates with $\geq 70 \%$ mass motility were pooled for each collection day for $10 \mathrm{wk}$ (100 pooled ejaculates). Pooled semen was diluted (1:20) and divided into 7 comparable portions and diluted (1:20) with TEYE either without antioxidant (control) or supplemented with $200 \mathrm{IU} C A T, 400 \mathrm{IU} C A T, 0.4 \mathrm{mM} \mathrm{GSH}, 0.8 \mathrm{mM}$ GSH, 150 IU SOD or 300 IU SOD (treated groups), respectively. Semen diluted with different types of TEYE was equilibrated at $5^{\circ} \mathrm{C}$ for $4 \mathrm{~h}$ and processed for freezing using $0.25 \mathrm{ml}$ French straws and stored at $-1960 \mathrm{C}$ for at least one month. Percentages of progressive motility ((SM), livability (SL) and acrosome damage (AD) of sperm cells were determined in post-diluted, -equilibrated and-thawed semen. Results revealed insignificant differences for SM, SL and AD in post-diluted semen among all tested extenders. In post-equilibrated and post-thawed semen adding antioxidants to TEYE extender significantly improved $S M$, SL and AD $(P<0.05)$ than control. In post-equilibrated semen no significant differences were found in either $S M$ or SL among the 6 treated groups, while in post-thawed semen level of antioxidant was significantly $(P<0.05)$ effective in this concept, where $400 \mathrm{IU} C A T$, $0.4 \mathrm{mM} \mathrm{GSH}$ and $300 \mathrm{IU}$ SOD were superior than $200 \mathrm{IU} C A T, 0.8 \mathrm{mM} \mathrm{GSH}$ and $150 \mathrm{IU} S \mathrm{SOD}$, respectively. Conception rate was the highest $(75 \%, P<0.05)$ for buffalo cows inseminated with semen supplemented with $400 \mathrm{IU}$ CAT, 0.4 GSH or 300 SOD and the least CR (58.3\%) was recorded for control semen. In conclusion, high level of catalase (400 vs. $200 \mathrm{IU}$ ) or superoxide dismutase (300 vs. $150 \mathrm{IU})$ and low level of reduced glotathion $(0.4$ vs. $0.8 \mathrm{mM}$ ) as enzymatic antioxidants showed beneficial effects on some characteristics and fertilizing capacity of buffalo spermatozoa of frozen semen.

\section{Keywords: Buffalo semen, enzymatic antioxidants, fertilizing capacity \\ INTRODUCTION}

Buffalo spermatozoa contain comparatively more unsaturated fatty acids than in other species, like arachidonic and decosahexaenoic acids, which make them more vulnerable to lipid peroxidation (Sreejith et al., 2005).

Issued by The Egyptian Society of Animal Production 
During various processing procedures of freezing semen, sperm cells used in AI are exposed to oxygen and visible light radiation, which could lead to lipid peroxidation and formation of ROS, which negatively affect sperm cell motility and genomic integrity (Bilodeau et al., 2000). The endogenous antioxidative capacity of semen may be insufficient during storage or dilution (Maxwell and Salamon, 1993). A significant reduction in the level of spermatozoa antioxidant been reported as one of the causes of the enhanced susceptibility of these cells to peroxidative injuries after cryopreservation (Bilodeau, et al., 2000). So, adding several types of antioxidant enzymes active in scavenging ROS, which could help to maintain survival and motility of spermatozoa (Bilodeau et al., 2000 and Foote et al., 2002).

The lipid peroxidation cascade is initiated when spermatozoa are attacked by ROS, which results in a loss of polyunsaturated fatty acids from the plasma membrane and a corresponding decline in the survival and fertilizing ability of these spermatozoa (Aitken, 1995). Sperm oxidative damage is the result of an improper balance between ROS generation and scavenging activities. In vitro studies suggested that the addition of CAT (Abdel-Khalek et al., 2009), GSH (Ahmed, 2008) or SOD (El-Nagar, 2008) to diluted semen could improve the motility and survival of buffalo bull spermatozoa in frozen semen as compared to controls. However, there is no information on the comparison of the beneficial effects of these enzymes on buffalo sperm function and fertility. Therefore, the current work aimed to compare the effects of adding different types and levels of enzymatic antioxidants (200 and $400 \mathrm{IU}$ of CAT), 0.4 and $0.8 \mathrm{mM}$ of GSH or 150 and $300 \mathrm{IU}$ of SOD to Tris-egg yolk extender on some characteristics and fertility of buffalo spermatozoa of frozen semen.

\section{MATERIALS AND METHODS}

\section{Semen collection:}

Five sexually mature buffalo bulls aged 4-7 years and weighed 548.6 \pm 11.24 were used for semen collection. All bulls were healthy and clinically free of external and internal parasites. Palpation of the external genitalia showed that they were typically normal. Semen was collected during autumn, 2009 by artificial vagina set up at optimal conditions to induce a good ejaculatory thrust. On day of collection, one false mount had been allowed before collection of the experimental ejaculates. Semen was collected twice weekly from each bull, where immediately after collection, ejaculates were held in a water bath at $35-37^{\circ} \mathrm{C}$, before being transferred to the laboratory. Ejaculates having good mass motility $(>70 \%)$ were pooled for each collection day.

\section{Semen extension:}

Total of 100 ejaculates were obtained during a collection period of 10 weeks. The main extender used for semen dilution was Tris-egg yolk extender (TEYE) containing $3.025 \mathrm{~g}$ Tris (hydroxymethyl amino methane, $1.675 \mathrm{~g}$ citric acid, $0.75 \mathrm{~g}$ glucose, $15 \mathrm{ml}$ egg yolk, $7 \mathrm{ml}$ glycerol, $0.005 \mathrm{~g}$ streptomycin, $0.25 \mathrm{~g}$ lincospectin and completed with bi-distilled water up to $100 \mathrm{ml}$. Total of 7 extenders, 6 of them with 3 types of antioxidant with two levels including CAT (200 and 400 IU), GSH (0.4 and $0.8 \mathrm{mM}$ ) and SOD (150 and $300 \mathrm{IU})$ were compared to extender without additive (control). The dilution rate was 1:20. The Tris-egg yolk extender was gently mixed and warmed up to $37 \mathrm{oC}$ in a water bath during semen extension. Vials containing the 
extended semen were placed in a water bath at $37^{\circ} \mathrm{C}$ and cooled gradually in a refrigerator at $5^{\circ} \mathrm{C}$ for 4 hours as an equilibration period.

\section{Freezing processes:}

For gradual cooling, straws were kept in iced water both to keep its temperature at $5^{\circ} \mathrm{C}$, while semen packed in straws was placed in a cooled ice chest. Postequilibration, the extended semen was loaded in $0.25 \mathrm{ml}$ French straws using a semen filling machine. During packaging in straws, extended semen was kept in an ice water bath at $5^{\circ} \mathrm{C}$. Straws were transferred into a processing canister and located horizontally in static nitrogen vapor $4 \mathrm{~cm}$ above the surface of liquid nitrogen for 10 minutes. The straws were then placed vertically in a metal canister and immersed completely in liquid nitrogen container for storage at $-196^{\circ} \mathrm{C}$. Each straw was titled for each supplementation and collection week then stored for at least one month.

\section{Semen evaluation:}

Percentages of SM (Amman and Hammerstedt, 1980), SL (Hancock, 1951) and AD (Watson, 1975) were determined in post-diluted and post-equilibrated semen during freezing process as well as in post-thawed semen (20 straws for each extender). For thawing, straws were dipped into a water bath at $37-38^{\circ} \mathrm{C}$ for 30 seconds.

\section{Conception rate (\%):}

Total of 84 sexually mature buffalo cows aged 3.5-8 years, weighed $520.14 \pm 18.47 \mathrm{~kg}$ and between 2 and 5 parities were randomly divided into 7 groups (12 animals in each group) according to age, LBW and parity. Each buffalo cow in heat was artificially inseminated with semen containing different antioxidant supplements. Inseminated buffalo cows were diagnosed for pregnancy on day 40 post-insemination for determination of conception rate.

\section{Statistical analysis:}

Data obtained in this study were statistically analyzed using computer program of SAS (2004). One way ANOVA was used to perform the effects of type and level of some antioxidants. Multiple rang test (Duncan, 1955) was employed to test statistical differences among means at $\mathrm{P}<0.05$. However, conception rate was analyzed using Chi square analysis. The percentage values were subjected to arcsine transformation before performing the analysis of variance. Means were presented after being recalculated from transformed values to percentages.

\section{RESULTS AND DISCUSSION}

\section{Sperm progressive motility(SM):}

Results shown in Table (1) revealed insignificant effect of antioxidant supplementation on SM in post-diluted semen. This indicated the absence of any effect of either the source or the level of antioxidant on SM after dilution of buffalo semen (Abdel-Khalek et al., 2009, El-Nagar, 2008 and El-Seify et al., 2009). Table (1) further shows that all antioxidant supplements significantly $(\mathrm{P}<0.05)$ increased $\mathrm{SM}$ in post-equilibrated and post-thawed semen than the control. Moreover, no significant differences were found among the various antioxidant supplements in this concept in post-equilibrated semen and the highest SM was recorded for 400 IU CAT $(65.6 \%)$ and the lowest one for $0.4 \mathrm{mM} \mathrm{GSH}(62.5 \%)$. On the contrary, SM in post- 
thawed semen significantly differed $(\mathrm{P}<0.05)$ among antioxidant supplemented levels, being significantly $(\mathrm{P}<0.05)$ higher $57.9,54.5$ and $56.3 \%$ for 400 IU CAT, 0.4 IU GSH and $300 \mathrm{mM}$ SOD than $47.3,47.3$ and $45.5 \%$ for 200 IU CAT, 0.8 IU GSH and $150 \mathrm{mM}$ SOD, respectively.

Table 1. Effect of antioxidant supplementation on percentages of sperm progressive motility in post-diluted, post-equilibrated and post-thawed of Buffalo semen

\begin{tabular}{cccc}
\hline \multirow{2}{*}{ Extenders } & \multicolumn{3}{c}{ Sperm progressive motility (\%) in semen } \\
\cline { 2 - 4 } & Post-dilution & Post-equilibration & Post-thawing \\
\hline Control & 71.8 & $53.6 \mathrm{~b}$ & $34.3 \mathrm{c}$ \\
+200 IU Catalase & 72.3 & $63.1 \mathrm{a}$ & $47.3 \mathrm{~b}$ \\
+400 IU Catalase & 72.3 & $65.6 \mathrm{a}$ & $57.9 \mathrm{a}$ \\
+0.4 mM GSH1 & 70.6 & $62.5 \mathrm{a}$ & $54.5 \mathrm{a}$ \\
+0.8 mM GSH1 & 70.5 & $62.6 \mathrm{a}$ & $47.3 \mathrm{~b}$ \\
+150 IU SOD2 & 70.6 & $62.6 \mathrm{a}$ & $45.5 \mathrm{~b}$ \\
+300 IU SOD2 & 71.8 & $65.1 \mathrm{a}$ & $56.3 \mathrm{a}$ \\
土SEM & 1.12 & 1.41 & 1.87 \\
\hline
\end{tabular}

a,b and c: Means within the same column with different superscripts are significantly different at $\mathrm{P}<0.05$.

$1 \mathrm{GSH}=$ Reduced glutathione $\quad 2 \mathrm{SOD}=$ Superoxide dismutase

These results are in agreement with those previously reported by El-Gaafary et al. (1990) and Fatouh and Abdou (1991) who observed an increase in sperm motility of bull semen supplemented with different CAT levels to egg yolk extender and semen stored at $5^{\circ} \mathrm{C}$. El-Seify et al. (2009) and Abdel-Khalek et al. (2009) also found that buffalo semen extended with extender containing high CAT levels (400 and 1000 IU) resulted in higher viability indices than both low CAT level as well as the control un supplemented semen. Such effect was associated with the lowest energy utilization in extender containing high CAT level (1000 IU), whereas the highest utilization was observed in extender containing low level of CAT (125 IU).

It is worthy noting that low GSH level $(0.4 \mathrm{mM})$ and high SOD level (300 IU) had benefits on sperm motility in post-thawed semen as compared to high GSH level $(0.8 \mathrm{mM})$ and low SOD level (150 IU) and both $0.4 \mathrm{mM}$ GSH and $150 \mathrm{IU}$ SOD levels did not differ significantly than $400 \mathrm{IU}$ of CAT. In the same line, Ahmed (2008) found that increasing level of GSH more than $0.4 \mathrm{mM}$ did not affect significantly sperm motility in post-thawed buffalo semen. Also, the observed improvement in sperm motility was attributed to that SOD was able to attenuate the inhibition of sperm motility induced by a high concentration of ROS (Mammoto et al., 1996). In addition, inclusion of SOD significantly delayed the destabilization of sperm plasma membrane associated with frozen storage of sperm cells (Maxwell and Stojanov, 1996).

\section{Sperm livability (SL):}

Results presented in Table (2) indicate insignificant effect of antioxidant supplementation on SL in post-diluted semen. Similar results were obtained on the effect of SOD (El-Nagar, 2008), GSH (Ahmed, 2008) or CAT (El-Seify et al., 2009) 
In both post-equilibrated and post-thawed semen, antioxidant supplementation significantly $(\mathrm{P}<0.05)$ improved SL in comparing with the control, however, no significant differences were found due to either type or level of supplemented antioxidant in this concept. However, in post-thawed semen, the SL values were significantly affected $(\mathrm{P}<0.05)$ by level of antioxidant. Values of SL obtained by 400 IU CAT, 0.4 IU GSH and $300 \mathrm{mM}$ SOD supplemented extenders were significantly superior $(60.5,62.4$ and $59.5 \%$ versus $50.1,55.8$ and $50.1 \%$ ) obtained by 200 IU CAT, 0.8 IU GSH and $150 \mathrm{mM}$ SOD, respectively (Table 2). This finding indicates the impact of $0.4 \mathrm{mM}, 300$ IU SOD or 400 IU CAT on sperm livability in frozen buffalo semen.

Table 2. Effect of antioxidant supplementation on percentages of sperm livability in post-diluted, post-equilibrated and post-thawed of Buffalo semen

\begin{tabular}{cccc}
\hline \multirow{2}{*}{ Extenders } & \multicolumn{3}{c}{ Sperm livability (\%) in semen } \\
\cline { 2 - 4 } & Post-dilution & Post-equilibration & Post-thawing \\
\hline Control & 72.2 & $55.1 \mathrm{~b}$ & $36.1 \mathrm{c}$ \\
+200 IU Catalase & 73.7 & $66.5 \mathrm{a}$ & $50.1 \mathrm{~b}$ \\
+400 IU Catalase & 73.8 & $68.3 \mathrm{a}$ & $60.5 \mathrm{a}$ \\
+0.4 mM GSH1 & 73.0 & $69.7 \mathrm{a}$ & $62.4 \mathrm{a}$ \\
+0.8 mM GSH1 & 73.6 & $69.6 \mathrm{a}$ & $55.8 \mathrm{~b}$ \\
+150 IU SOD2 & 73.4 & $69.0 \mathrm{a}$ & $50.1 \mathrm{~b}$ \\
+300 IU SOD2 & 73.2 & $69.2 \mathrm{a}$ & $59.5 \mathrm{a}$ \\
\pm SEM & 0.95 & 1.24 & 1.61 \\
\hline
\end{tabular}

a,b and c: Means in the same column with different superscripts significantly differed, $\mathrm{P}<0.05$. $1 \mathrm{GSH}=$ Reduced glutathione $\quad 2 \mathrm{SOD}=$ Superoxide dismutase

The addition of CAT was found to have positive effects in maintaining the bull SL in an egg yolk extender but not in milk extender (Foote et al., 2002). This lake may be due to the high content of antioxidants in milk casein (Taylor and Richardson, 1980). El-Seify et al. (2009) also observed increasing SL in postequilibrated and post-thawed buffalo semen with the high SOD and high CAT doses than low doses. Ahmed (2008) and Abdel-Khalek et al. (2009) also reported beneficial effect of a low GSH dose than a high one on SL in post-thawed buffalo semen.

\section{Acrosome status:}

Data in Table (3) show insignificant effect of antioxidant supplementation on percentage of sperm AD in post-diluted semen, which agrees with results reported by El-Nagar (2008), Ahmed (2008) and El-Seify et al. (2009). However, supplementation of 400 IU of CAT, $0.4 \mathrm{mM}$ of GSH or 300 IU of SOD to TEYE significantly $(\mathrm{P}<0.05)$ induced higher reduction in $\mathrm{AD}$ percentage in postequilibrated and post-thawed semen, being the best for CAT supplementation. Data available in the literature, showed that supplementation of TEYE with CAT (AbdelKhalek et al. 2009 and El-Seify et al., 2009), SOD (El-Nagar, 2008 and El-Seify et al., 2009) or GSH (Ahmed, 2008) have positive effects in maintaining higher percentage of sperm cell with intact acrosome in post-thawed buffalo semen. Moreover, Maxwell and Stojanove (1996) showed that CAT improved acrosome integrity of ram spermatozoa during liquid storage. 
Table 3. Effect of antioxidant supplementation on spermatozoa with damaged acrosome $\%$ in post-diluted, post-equilibrated and post-thawed semen

\begin{tabular}{cccc}
\hline \multirow{2}{*}{ Extenders } & \multicolumn{3}{c}{ Sperm with damage acrosome (\%) in semen } \\
\cline { 2 - 4 } & Post-dilution & Post-equilibration & Post-thawing \\
\hline Control & 24.8 & $41.0 \mathrm{a}$ & $58.7 \mathrm{a}$ \\
+ 200 IU Catalase & 26.3 & $32.0 \mathrm{bc}$ & $44.5 \mathrm{bc}$ \\
+ 400 IU Catalase & 22.7 & $28.5 \mathrm{c}$ & $33.2 \mathrm{e}$ \\
+ 0.4 mM GSH1 & 23.6 & $28.8 \mathrm{c}$ & $36.3 \mathrm{de}$ \\
+0.8 mM GSH1 & 22.8 & $29.8 \mathrm{c}$ & $42.8 \mathrm{c}$ \\
+ 150 IU SOD2 & 25.5 & $34.8 \mathrm{~b}$ & $48.1 \mathrm{~b}$ \\
+ 300 IU SOD2 & 23.7 & $29.0 \mathrm{c}$ & $37.2 \mathrm{~d}$ \\
tSEM & 1.59 & 1.51 & 1.44 \\
\hline
\end{tabular}

a,b.....d: Means in the same column with different superscripts significantly differed, $\mathrm{P}<0.05$.

$1 \mathrm{GSH}=$ Reduced glutathione $\quad 2 \mathrm{SOD}=$ Superoxide dismutase

\section{Conception rate (CR):}

Data in Table (4) recorded significantly higher CR 75\% $(9 / 12),(\mathrm{P}<0.05)$ for buffalo cows inseminated by semen diluted by 400 IU CAT, $0.4 \mathrm{mM}$ GSH or $300 \mathrm{IU}$ SOD supplemented TEYE than $66.7 \%(8 / 12)$ for those inseminated by semen extended with 200 IU CAT or 150 IU SOD and $58.3 \%,(7 / 12)$ for the control cows inseminated with semen having no antioxidants supplement. These finding agree with that reported by Abdel-Khalek et al. (2009) on the effect of CAT and GSH on CR of buffalo cows. In addition, Maxwell and Stojanov (1996) detected that pre-storage fortification of semen extender with SOD significantly enhanced the viability and fertilizing ability of stored spermatozoa.

Table 4. Effect of antioxidant supplementation on conception rate of buffalo cows inseminated with tested extenders

\begin{tabular}{|c|c|c|c|}
\hline \multirow[b]{2}{*}{ Extenders } & \multicolumn{3}{|c|}{ Sperm with intact acrosome damage (\%) in semen } \\
\hline & $\begin{array}{l}\text { Inseminated } \\
\text { animals }\end{array}$ & $\begin{array}{c}\text { Conceived } \\
\text { Animals }\end{array}$ & $\begin{array}{l}\text { Conception } \\
\text { Rate (\%) }\end{array}$ \\
\hline Control & 12 & 7 & $58.3 \mathrm{~b}$ \\
\hline +200 IU Catalase & 12 & 8 & $66.7 \mathrm{ab}$ \\
\hline +400 IU Catalase & 12 & 9 & $75.0 \mathrm{a}$ \\
\hline$+0.4 \mathrm{mM}$ GSH1 & 12 & 9 & $75.0 \mathrm{a}$ \\
\hline$+0.8 \mathrm{mM}$ GSH1 & 12 & 7 & $58.3 b$ \\
\hline +150 IU SOD2 & 12 & 8 & $66.7 \mathrm{ab}$ \\
\hline +300 IU SOD2 & 12 & 9 & $75.0 \mathrm{a}$ \\
\hline \multicolumn{4}{|c|}{$\begin{array}{l}\mathrm{a} \text { and } \mathrm{b} \text { : Means in the same column with different superscripts significantly differed, } \mathrm{P}<0.05 \text {. } \\
1 \mathrm{GSH}=\text { Reduced glutathione } \quad 2 \mathrm{SOD}=\text { Superoxide dismutase }\end{array}$} \\
\hline \multicolumn{4}{|c|}{$\begin{array}{l}\text { In general, low concentration of reactive oxygen species (ROS), including } \mathrm{H} 2 \mathrm{O} 2 \text {, } \\
\text { an be required to promote capacitation, leading to the acrosome reaction of } \\
\text { germatozoa (Griveau et al., 1994). However, substantial accumulations of ROS can } \\
\text { egatively affect reproductive function and affect sperm cells in a variety of ways } \\
\text { Aitken et al., } 1998 \text { and Shen et al., 1999), with peroxidative damage to sperm DNA } \\
\text { ad the plasma membrane. The increase in oxidative modification of proteins with } \\
\text { ging has been associated with oxygen-free radical generating systems. This increase }\end{array}$} \\
\hline
\end{tabular}


can be inhibited by CAT (Stadtman, 1992) SOD (Maxwell and Stojanove 1996) or GSH (El-Nenaey et al., 2006).

Protection of sperm against $\mathrm{H} 2 \mathrm{O} 2$ by the addition of catalase may be useful, particularly because bull semen contains little amount of catalase. In accordance with the present results, studies on dromedary camel semen showed the highest percentages of motility, live sperm and normal spermatozoa in semen diluted with extenders supplemented with $500 \mathrm{IU} / \mathrm{ml}$ of catalase (Medan et al., 2008). Also, Roca et al. (2005) found that addition of catalase to semen extender improved post-thaw sperm viability and fertility in boars. In addition, Sikka (2004) reported that catalase is a potent antioxidant and a very potent and efficient endogenous radical scavenger. It reacts with the highly toxic hydroxyl radical and provides protection against oxidative damage to biomolecules. De Lamirande and Gagnon (1995) stated that in vitro treatment of spermatozoa with SOD significantly inhibited the destabilization of periacrosomal sperm plasma membrane associated with sperm capacitation and acrosome reaction.

\section{REFERENCES}

Abdel-Khalek A.E., Laila, N. Eid, Sh.A. Gabr N.A. Shalaby and A.A. Gabr, 2009. Effect of different types and levels of antioxidants on viability and acrosomal status of frozen-thawed spermatozoa of buffalo bulls. J. Agric. Sci. Mansoura.Univ., 34(4):2853-2862.

Ahmed I.A., 2008. Effect of adding ascorbic acid to semen of Egyptian buffalo bulls. M. Sc. Fac. Agric. Mansoura University.

Aitken, R.J., 1995. Free radicals, lipid peroxidation and sperm function. Reproduction, Fertility and Development, 7, 659-668.

Aitken, R.J., E. Gordon, D. Harkiss, J.P. Twigg, P. Miline, Z. Jennings and D.S. Irvine, 1998. Relative impact of oxidative stress on the functional competence and genomic intergrity of human spermatozoa. Boil., Reporod., 59: 1037-1046.

Amann R.P. and R.H. Hammerstedt, 1980. Validation of a system for computerized measurements of spermatozoa velocity and percentage of motile sperm. Biol. Reprod., 23: 647-656.

Bilodeau J.F., S. Chatterjee, M.A. Sirard. and C. Gagnon, 2000. Levels of antioxidant defenses are decreased in bovine spermatozoa after cycle of freezing and thawing. Mol. Reprod. Dev., 55, 282-288.

De Lamirande E. and C. Gagnon, 1995. Impact of reactive oxygen species on spermatozoa a balancing act between beneficial and detrimental effects. Hum. Reprod., 10:15-21.

Duncan D.B., 1955. Multiple Ranges and Multiple F- test. Biometrics, 11:10.

El-Gaafary, M.N., A.H. Daader and A. E. Ziedan, 1990. Effects of caffeine on bull semen quality and sperm penetration into cervical mucus. Anim. Reprod. Sci., 23: 13-19.

El-Nagar H.A.A., 2008. Studies on frozen buffalo bull semen. Ph. D. Thesis, Fac. of Agric., Al-Azhar. Univ., Egypt.

El-Nenaey M.H., M.A. El-Sharbieny, A.E. Abdel-khalek, E.M.E. El-Siefy and M.M. El-baz, 2006. Effect of reduced glutathione supplementation on motility, livability and abnormality of Holstein spermatozoa in: 2- Frozen semen. J. Agric. Sci. Mansoura Univ., 31: 5005-5013. 
El-Siefy E.M.E., M.A.El-Sherbien, A.M.A.Hussein, H.A.B. Ganah and Sh.A.Gabr, 2009. Effect of antioxidant enzymes supplementation during different freezing stages on semen characteristics of Friesian bulls. Egyptian Soc. Anim. Reprod. Fert. Twenty First Annual Congr. Cairo/Hurgada, February 7-11, 2009. 253-266.

Fatouh, El-S.M. and M.S.S. Abdou, 1991. Effect of caffeine on the post-thaw motility of buffalo spermatozoa. Vet. Med. J. Egypt. 33: 261-277.

Foote R.H., C.C. Brockette and M.T. Kaproth, 2002. Motility and fertility of bull sperm in whole milk extender containing antioxidants. Anim. Prod. Sci., 71:13 23.

Griveau J.F., P. Renard and D. Lelannou 1994. An in vitro promoting role for hydrogen peroxide in human sperm capacitation. Int. J. Androl., 17: 300-307.

Hancock J.I., 1951. A staining technique for the study of temperature shock in semen. Nature, Lond., 167 : 223. 323-324.

Mammoto A., N. Masumoto, M. Tahara, Y. Lkebuchi, M.Ohmichi, K. Tasaka and A. Miyake, 1996. Reactive oxygen species block sperm-egg fusion via oxidation of sperm sulfhydryl proteins in mice. Biol Reprod., 55:1063-1068.

Maxwell W.M.C and S. Salamon, 1993. Liquid storage of ram semen. Reprod. Fertil. Dev., 5: 613-638.

Maxwell W.M and I. Stojanov, 1996. Liquid storage of ram semen in the absence or presence of some antioxidant. Reprod. Fertile. Dev., 8: 1013-1020.

Medan M.S., A. Gamal, E.Z Alaa, H.K. Medhat, H.K. Hesham, M.A. Atef and M.A. Tarek 2008. Survival and fertility rate of cooled dromedary camel spermatozoa supplemented with catalase enzyme. J. Of Reprod. And Development, 54: 84-89.

Roca J., M.J. Rodriguez, M.A. Gil, G. Carvajal, E.M. Garcia, C. Cuello, J.M. Vazquez and E.A. Martinez, 2005. Survival and in vitro fertility of boar spermatozoa frozen in the presence of superoxide dismutase and /or catalase. J. Androl., 26: 15-24.

SAS, 2004. SAS / Stat, SAS User's Guide: Version 9.1.3. SAS Institute, Cary, NC.

Shen H.M., S. E.Chia and C.N. Ong, 1999. Evaluation of oxidative DNA damage in human sperm and its association with male infertility. J. Androl., 20: 718-723.

Sikka S.C., 2004. Role of oxidative stress and antioxidants in andrology and assisted reproductive technology. J. Androl., 25: 5-18.

Sreejith J.N., A.S. Brar, S.P.S. Ahuja and K.C. Chaudhary, 2005. A comparative study on lipid peroxidation, activities of antioxidant enzymes and viability of cattle and buffalo bull spermatozoa during storage at refrigeration temperature. Animal Reproduction Science. Volume 96, Issues 1-2 p. 12-29.

Stadtman E. R., 1992. Protein oxidation and aging. Science. 257: 1220-1224.

Taylor, M.J. and T. Richardson, 1980. Antioxidant activity of skim milk effect of somification. J. Dairy Sci., 63: 1938-1942.

Watson P.F., 1975. Use of a Giemsa stain to detect changes in acrosomes of frozen ram spermatozoa. Vet. Re. $97: 12-15$. 
تأثثر أنواع ومستويات مختلفة من الإنزيمات المضادة للأكسدة علي بعض صفات والقدرة الإخصابية للسائل المنوي المجمد لطلائق الجاموس الأزيمات

شريف عبد الونيس جبر

قسم الإنتاج الصيوانس، كلية الزراعة، جامعة طنطا

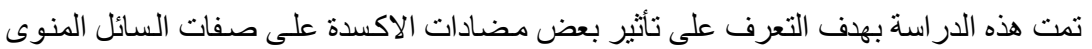

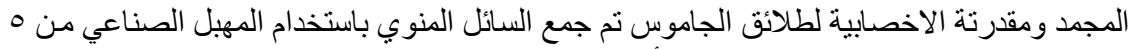

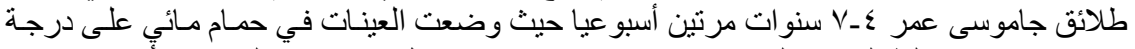

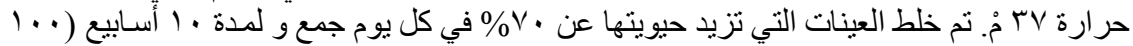

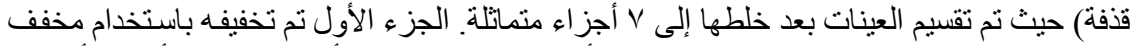

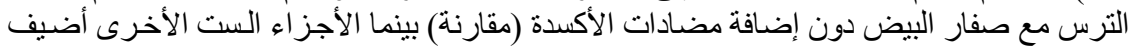

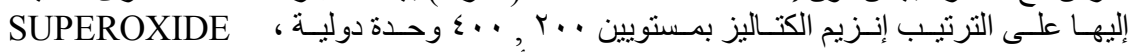

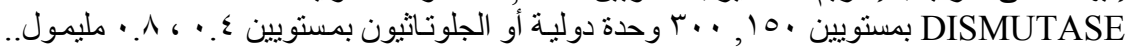

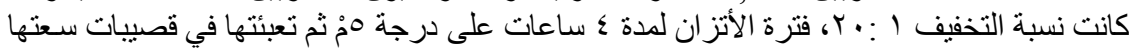

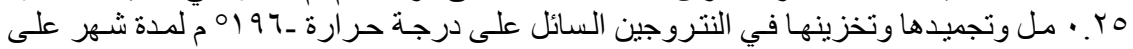

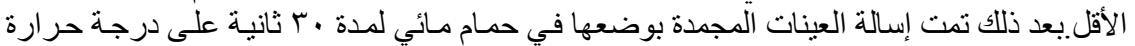

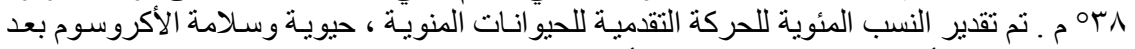

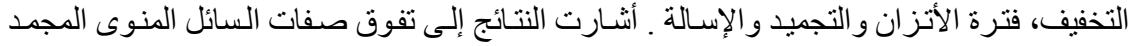

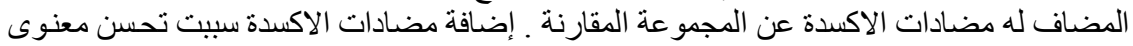

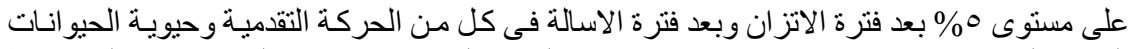

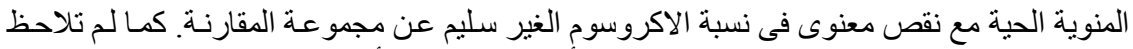

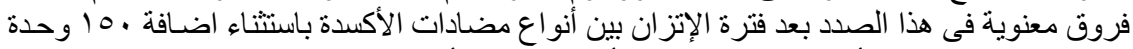

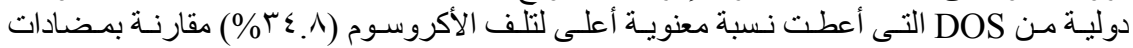

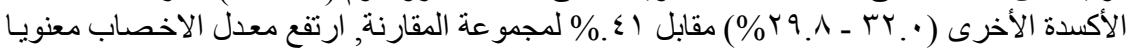

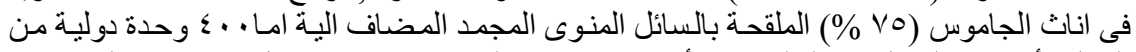

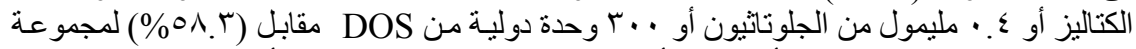

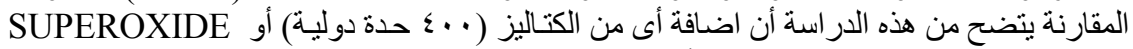

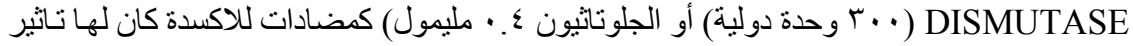
فعال على المقدرة التخزينية والقدرة الإخصابية للسائل المنوى الجاموسى ألئ 